\title{
Blue Nile incision on the Ethiopian Plateau: Pulsed plateau growth, Pliocene uplift, and hominin evolution
}

\author{
Nahid DS Gani*, M. Royhan Gani*, Energy \& Geoscience \\ Institute, University of Utah, 423 Wakara Way, Suite 300, \\ Salt Lake City, Utah 84108, USA; Mohamed G. Abdelsalam, \\ Geological Sciences and Engineering, University of Missouri, \\ 123 McNutt Hall, Rolla, Missouri 65409, USA
}

\begin{abstract}
The 1.6-km-deep Gorge of the Nile, a rival of the Grand Canyon, resulted from the deep incision of the Blue Nile drainage into the uplifted Ethiopian Plateau. Understanding the incision history of the plateau is crucial to unraveling the Cenozoic tectonoclimatic evolution of the region, particularly because the region has long been used as a natural laboratory to understand the geodynamics of continental rifting and the evolution of hominins. We undertake a quantitative geomorphologic approach integrating field, geographic information system (GIS), and digital elevation model (DEM) data to analyze incision (volume, long-term rates, and spatiotemporal variability) and river longitudinal profiles of the Blue Nile drainage. Previously published isotopic ages of the Cenozoic volcanic rocks are used to constrain long-term incision rates through geologic time.

Our data argue that (1) the Blue Nile drainage has removed at least 93,200 $\mathrm{km}^{3}$ of rocks from the northwestern Ethiopian Plateau since ca. $29 \mathrm{Ma}$ (early Oligocene) through a three-phase (ca. 29-10 Ma, ca. 10-6 Ma, and ca. $6 \mathrm{Ma}$ to present) incision, where long-term incision rates increased rapidly and episodically in the late Miocene (ca. $10 \mathrm{Ma}$ and ca. $6 \mathrm{Ma}$ ); (2) being out-ofphase with the past climatic events and in-phase with the main volcanic episodes of the region, this episodic increase of incision rate is suggestive of episodic growth of the plateau; (3) of the $\sim 2-\mathrm{km}$ rock uplift of the plateau since ca. $30 \mathrm{Ma}, 0.3 \mathrm{~km}$ was due to isostatic uplift related to erosional unloading, and the rest was due to other tectonic activities; (4) the extremely rapid long-term incision rate increase, thus a rapid uplift of the plateau, ca. 6 Ma might be related to lithospheric foundering, caused by ponded plume material beneath the Ethiopian Plateau and aided by huge tectonic stresses related to the Messinian salinity crisis of the Mediterranean Sea. These events could have caused the plateau to rise $>1 \mathrm{~km}$ within a few m.y. in the early Pliocene. This uplift history of the Ethiopian Plateau can shed critical light on the geodynamics of the Afar mantle plume and the evolution of the East African hominins via climate change.
\end{abstract}

\section{INTRODUCTION}

In tectonically active regions, landscape evolution is controlled, mostly in a feedback loop, by tectonics, climate, topography, and surface geomorphic processes. These factors are responsible for shaping the world's most spectacular tec- tonically active landscapes, including the Himalayas, Rockies, Alps, Pyrenees, Andes, and Southern Alps (New Zealand). The erosional history of the Colorado (e.g., Pederson et al., 2002; McMillan et al., 2006, and references therein) and the Tibetan plateaus (e.g., Clark et al., 2004; Schoenbohm et al., 2004, and references therein), both situated within collisional orogenic belts, are well studied. Conversely, studies of the erosional history of the non-orogenic Ethiopian Plateau are few and preliminary (McDougall et al., 1975; Weissel et al., 1995; Pik et al., 2003). Relative to other elevated regions where direct glacial erosion is pronounced, the Ethiopian Plateau is least affected by Cenozoic global cooling and/or Pleistocene glacial cycles because of its location close to the equator (cf. Molnar and England, 1990). Moreover, because of its non-orogenic setting, tectonic exhumation of the Ethiopian Plateau is insignificant. Therefore, river incision and plateau uplift (tectonic and/or isostatic) have a more direct coupling for the Ethiopian Plateau.

The Blue Nile, a major tributary of the Nile River, extensively dissected the northwestern Ethiopian Plateau (Fig. 1), exposing igneous, metamorphic, and sedimentary rock units ranging in age from Neoproterozoic to Holocene (Figs. 2 and 3). The plateau is also characterized by the deeply incised Gorge of the Nile (Fig. 3; Gani and Abdelsalam, 2006), the deepest and most extensive canyon in the greater Nile drainage basin and a rival of the Grand Canyon of the Colorado Plateau.

In the Late Jurassic, the plateau was below sea level for the last time, as indicated by the deposition of marine Upper Limestone overlain by Cretaceous-age continental-fluvial Upper Sandstone (Gani and Abdelsalam, 2006). Today, the contact between the
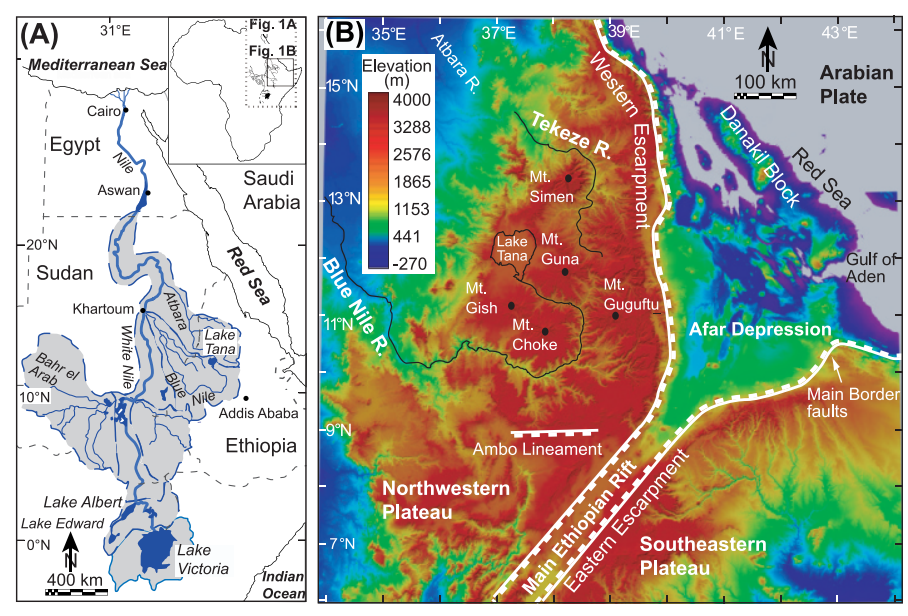

Figure 1. (A) Drainage basin of the Nile, the longest river on Earth, along with its major tributaries, including the Blue Nile. (B) Color-coded hillshade Shuttle Radar Topography Mission digital elevation model of the Ethiopian Plateau. Note locations of the Blue Nile and Tekeze drainage network and major tectonic elements.

GSA Today: v. 17, no. 9, doi: 10.1130/GSAT01709A.1

*E-mails: Nahid DS Gani: ngani@egi.utah.edu; M. Royhan Gani: rgani@egi.utah.edu 
Upper Limestone and Upper Sandstone lies at an average elevation of $2.2 \mathrm{~km}$, which is grossly the net rock uplift of the plateau since ca. 150 Ma. However, partitioning of the plateau uplift in geologic time, particularly during the Cenozoic, is poorly understood and debated (Faure, 1973; McDougall et al., 1975; Weissel et al., 1995; Pik et al., 2003; Ayalew and Yamagishi, 2004). Erosional studies of the northwestern Ethiopian Plateau are also in conflict. Based on fractal analysis of drainage network, Weissel et al. (1995) suggested that flexural uplift (i.e., isostatic rebound of the lithosphere due to rifting) of the Western flank of the Main Ethiopian Rift in the late Miocene resulted in the establishment of a new drainage network that controlled the subsequent erosion of the

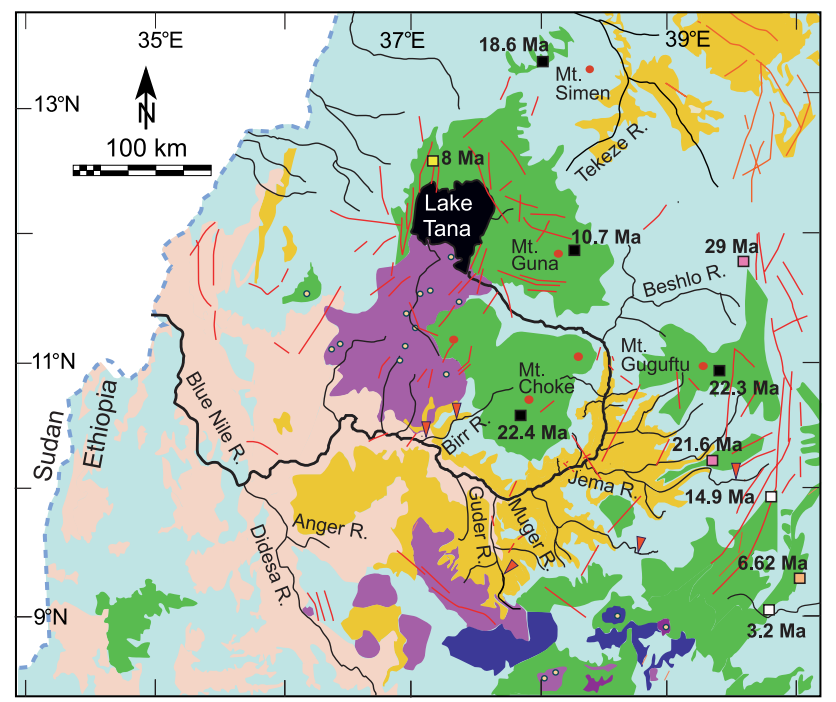

Ethiopian Plateau. Pik et al. (2003), on the other hand, based mainly on apatite (U-Th)/He thermochronometry, concluded that erosion in the $\mathrm{Bl}$ ue Nile drainage initiated between 29 and $25 \mathrm{Ma}$ and inferred that the present-day elevated and eroded plateau physiography has existed since the late Oligocene. Therefore, further study to constrain the incision of the plateau in time and space is required to better understand the uplift history of the Ethiopian Plateau. This study can also shed critical light on the regional geodynamics as well as paleoclimate and hominin evolution of East Africa, considering that the Afar (Fig. 1) hosts some of the oldest and the most complete fossil remains of hominins, including Lucy and Dikika baby.

Here, we present results of quantitative geomorphologic analysis of the Blue Nile drainage in the northwestern Ethiopian Plateau, integrating field data, geographic information system (GIS), and digital elevation model (DEM) information extracted from a Shuttle Radar Topography Mission (SRTM). The objective is to analyze plateau incision (depth, long-term rates, and spatiotemporal variability) and river longitudinal profiles. The results are discussed in relation to the tectonic and climatic history of the region. of volcanic rocks and major knickpoints in tributary profiles of Figure 6C and GSA Data Repository Figure DR3 (see text footnote 1).
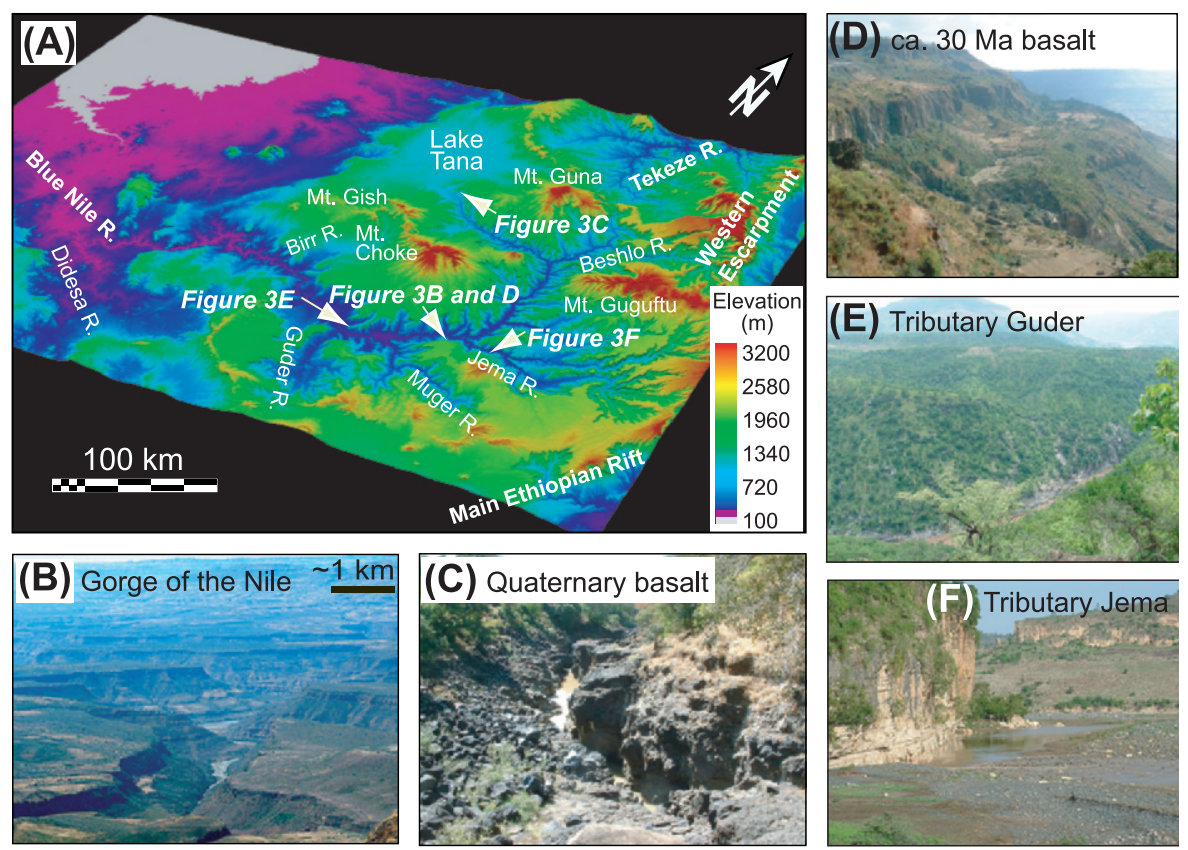

Figure 3. (A) The Blue Nile with major tributaries in three-dimensional perspective generated from a Shuttle Radar Topography Mission digital elevation model. (B) Gorge of the Nile where the Blue Nile deeply dissected the Mesozoic sedimentary rocks. (C) Relatively young incision of the Blue Nile through Quaternary basalts close to its source at Lake Tana. (D) 30 Ma basalts exposed near the confluence of tributary Muger. (E) Neoproterozoic basement rocks exposed at tributary Guder. (F) Late Jurassic Upper Limestone exposed at tributary Jema.

\section{GEOLOGIC SETTING}

The northwestern Ethiopian Plateau, with a mean elevation of $2.5 \mathrm{~km}$, is located on the western flank of the tectonically active Main Ethiopian Rift and the Afar Depression (Fig. 1B). The plateau was uplifted due to the combined effects of the rising Afar mantle plume and flank uplift of the Main Ethiopian Rift and the Afar Depression (Collet et al., 1999; Şengör, 2001; Davis and Slack, 2002; Beyene and Abdelsalam, 2005). A tectono-chronostratigraphic calculation led Şengör (2001) to conclude that the 1000-km-diameter Afar dome began to rise in the middle Eocene, reaching an elevation of $\sim 1 \mathrm{~km}$ by the early Oligocene. Extensive basaltic flows (500-2000 $\mathrm{m}$ thick) were erupted over a short, $1 \mathrm{~m} . \mathrm{y}$., interval ca. $30 \mathrm{Ma}\left({ }^{40} \mathrm{Ar} /{ }^{39} \mathrm{Ar}\right.$ age dating and magnetostratigraphy of Hofmann et al., 1997). This eruption, covering an area of $>500,000 \mathrm{~km}^{2}$, is inferred to mark the appearance of the Afar mantle plume (Mohr and Zanettin, 1988; Hofmann et al., 1997; Kieffer et al., 2004). Plume-related uplift caused deep-seated 
faults within the Ethiopian lithosphere, leading to the collapse that formed the Afar Depression ca. 24 Ma (Capaldi et al., 1987; Beyene and Abdelsalam, 2005). This event was followed by shield-volcano-building episodes, which gave rise to the development of Choke and Guguftu volcanoes (Figs. 1B and $3 \mathrm{~A})$ in the northwestern Ethiopian Plateau ca. $22 \mathrm{Ma}\left({ }^{40} \mathrm{Ar} /{ }^{39} \mathrm{Ar}\right.$ ages of Kieffer et al., 2004).

After the initiation of rifting, the Danakil block (Fig. 1B) started to separate from the Nubian Plate ca. $20 \mathrm{Ma}$ (Manighetti et al., 2001; Beyene and Abdelsalam, 2005). Based on geochronology (Ar/Ar), Wolfenden et al. (2004) suggested that the northern Main Ethiopian Rift, which dissected the Ethiopian Plateau into northwest and southeast sections (Fig. 1B), developed ca. 11 Ma. Meanwhile, the Guna shield volcano (Figs. 1B and 3A) formed at 10.7 Ma (Ar/Ar ages of Kieffer et al., 2004). WoldeGabriel et al. (1990), based on stratigraphic relationships and geochronological (K/Ar) studies, proposed that the western boundary fault of the Main Ethiopian Rift initiated by at least $8.3 \mathrm{Ma}$. However, in a recent structural, petrological, and geochronological (K/Ar) study, Bonini et al. (2005) concluded that extension forming the Main Ethiopian Rift started between 6 and $5 \mathrm{Ma}$. Lake Tana appeared ca. $8 \mathrm{Ma}$, marked by the deposition of lignitiferous sediments (Chorowicz et al., 1998).

\section{METHODS}

As demonstrated by Pederson et al. (2002), McMillan (2003), and McMillan et al. (2006), the uplift and incision history of a region can be documented and evaluated through GIS analysis using DEM and stratigraphic markers. We take a similar approach (see the GSA Data Repository ${ }^{1}$ ) using a SRTM-generated DEM with a horizontal resolution of $90 \mathrm{~m}$ and vertical accuracy of \pm 30 $\mathrm{m}$ (Gani and Abdelsalam, 2006). Thirty $1^{\circ} \times 1^{\circ}$ DEM tiles covering the Blue Nile and the southern part of the Tekeze drainage in the northwestern Ethiopian Plateau were resampled and mosaiced into a single DEM file (Fig. 4A).
In the study area, near-horizontal Mesozoic sedimentary strata are sandwiched between Neoproterozoic basement and volcanic rocks younger than $31 \mathrm{Ma}$ (Gani and Abdelsalam, 2006). Our map of these volcanic rocks (Fig. 2) is based on field observations, the geologic map of Ethiopia (Mangesha et al., 1996), and other published accounts (Hofmann et al., 1997; Ukstins et al., 2002; Coulie et al., 2003; Pik et al., 2003; Kieffer et al., 2004; Wolfenden et al., 2004). Scattered topographic highs, except sharply elevated volcanic peaks, of these volcanic rocks (preserved as erosional remnants; Fig. 4A) were used to construct a diachronous paleodatum surface (Fig. 4B), applying a nearest-neighbor triangulation algorithm (provided in the GSA Data Repository [see footnote 1]). This paleodatum surface is a composite imaginary (as if no incision happened) surface, ranging in age from early Oligocene (ca. $30 \mathrm{Ma}$ ) to Quaternary. Regional incision over the northwestern Ethiopian Plateau was mapped by subtracting modern topography from the paleodatum surface (Fig. 4C).

To quantify the long-term incision rates of the Ethiopian Plateau, we exploit the available isotopic ages of the Cenozoic volcanics (Fig. 2; Table DR1, GSA Data Repository [see footnote 1]). Thermochronological studies indicate that the erosion at the Blue Nile and Tekeze drainage initiated ca. 29 Ma (Pik et al., 2003), shortly after the extensive flooding by a thick (average $\sim 1 \mathrm{~km}$ ) basalt ca. $30 \mathrm{Ma}$. This basalt would have buried preexisting relief of the Ethiopian Plateau and led to fresh regional incision by establishing a new drainage network. Pik et al. (2003) argued, based on thermochronology, ages of volcanic divides, curvature of stratigraphic contacts, and the morphology of the drainage basin, that the present-day overall paths of the Blue Nile and Tekeze rivers were established between 30 and $23 \mathrm{Ma}$. Therefore, it is assumed that the ages $(<31 \mathrm{Ma})$ of the erosional remnants (Fig. $4 \mathrm{~A}$ ) give the earliest ages of incision initiations at those locations. We (1) calculate long-term incision rates (dividing the maximum incision depth around a dated remnant by the remnant age, yielding an aver-
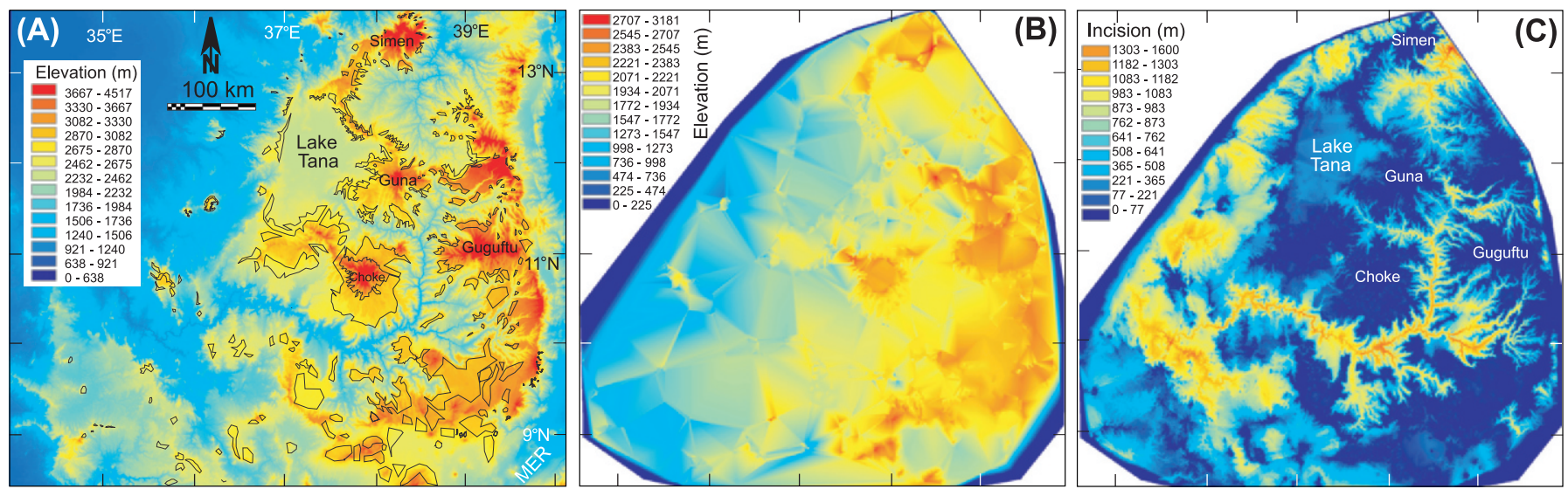

Figure 4. (A) Color-coded map showing present-day elevation of study area. Polygons are drawn around high erosional remnants, excluding volcanic peaks and ridges (see GSA Data Repository [text footnote 1]). (B) Reconstruction of a diachronous paleodatum surface by interpolating erosional remnants. This surface gives a minimum estimate of the elevation of the former zero-incision landscape (relative to modern topography). (C) Colorcoded incision map generated by subtracting modern topography (A) from the paleodatum surface (B). The incision pattern broadly follows the presentday Blue Nile and Tekeze drainage network. The deepest incision occurred at the western margin of the plateau where the Blue Nile and Tekeze River leave the plateau.

${ }^{1}$ GSA Data Repository Item 2007217, Methods: Stratigraphic-GIS-DEM analysis to quantify incision, Figures DR1-DR3 and Table DR1, is available at www.geosociety.org/pubs/ft2007.htm. You can also obtain a copy by writing to editing@geosociety.org. 
age incision rate) at various places on the plateau; (2) plot the long-term incision rates against the ages of the remnants; and (3) draw best-fit lines enveloping the maximum incision rates to demonstrate the variations of long-term incision rates since ca. $29 \mathrm{Ma}$ (Fig. 5). Notably, without proper caution, these types of plots are vulnerable to spurious self-correlation (i.e., auto-correlation between two parameters having a common term; e.g., Kenney, 1982) or to the effect of variable observation spans (e.g., Gardner et al., 1987). Although these issues might be a secondary factor, they do not exert a first-order control in our data analysis (see GSA Data Repository).

\section{RESULTS}

\section{Plateau Incision in Time and Space}

In the northwestern Ethiopian Plateau, incision varies from 0 to $1.6 \mathrm{~km}$ (Fig. $4 \mathrm{C}$ ). The incision pattern broadly follows the present-day Blue Nile and Tekeze drainage network, where higher magnitude incision characterizes the main course of the Blue Nile. The deepest incision occurred at the western margin of the plateau (Fig. 4C), where the Blue Nile and the Tekeze River leave the plateau (Fig. 1). Both incision and valley width, neither of which are controlled primarily by bedrock lithology or structure (Gani and Abdelsalam, 2006; Gani, 2006), gradually decrease upstream. Incision also decreases upstream from the confluence points of the Blue Nile with its tributaries Guder, Muger, and Jema (Figs. 3A and 4C). These incision patterns are characteristic of headward migration of knick faces, suggesting that Gorge of the Nile excavation was done mostly by headward erosion. The minimum volume of rocks removed as a result of these incisions (and other slope-failure processes) since ca. $29 \mathrm{Ma}$ is calculated (by creating a "Cut/Fill" surface in ArcGIS) to be at least $93,200 \mathrm{~km}^{3}$. These removed rocks were subsequently deposited as sediments in alluvial fans of Sudan and in the Nile Delta and Nile Fan of the Mediterranean (e.g., Garzanti et al., 2006). The northwestern Ethiopian Plateau supplies 96\% of the Nile sediment load (Garzanti et al., 2006) through the Blue Nile and Tekeze drainage incision. Therefore, the incision history and eroding rock volume of the Ethiopian Plateau would significantly control the sediment budget and evolution of the Nile Delta and Nile Fan.

The incision history of the northwestern Ethiopian Plateau can be divided into three phases, based on the variation of long-term incision rates (average rates from a particular geologic time to the present) of the drainage basin (Fig. 5). Phase I, ca. 29 to ca. $10 \mathrm{Ma}$, is characterized by low, long-term incision rates that slowly and steadily rose from 53 to $80 \mathrm{~m} / \mathrm{m}$.y. $(0.053-0.080 \mathrm{~mm} / \mathrm{yr})$. Phase II, ca. $10 \mathrm{Ma}$ to ca. $6 \mathrm{Ma}$, is an intermediary incision phase during which long-term rates increased from 80 to $120 \mathrm{~m} / \mathrm{m} . y(0.080-0.12 \mathrm{~mm} / \mathrm{yr})$. Phase III, from $6 \mathrm{Ma}$ to the present, is characterized by high, long-term incision rates that increase exponentially from 120 to $320 \mathrm{~m} / \mathrm{m}$.y. $(0.12-0.32 \mathrm{~mm} / \mathrm{yr})$.

\section{River Longitudinal Profiles}

Analysis of the shape of a river long-profile is a powerful tool in determining the incision and uplift history of a region (Weissel and Seidl, 1998; Schoenbohm et al., 2004; Clark et al., 2005; Crosby and Whipple, 2006). Change in the base level (e.g., increase in uplift rate, surface rupture on faults, stream capture)

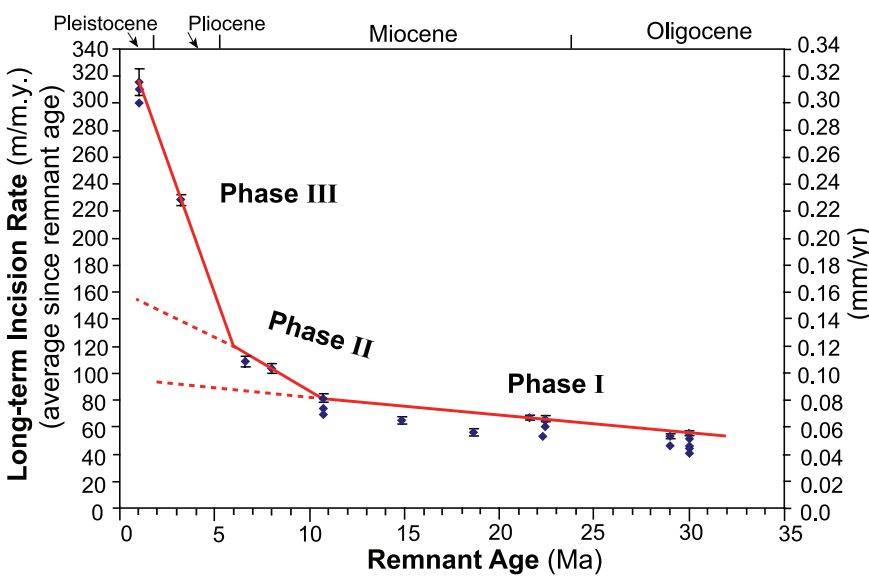

Figure 5. Long-term incision rate versus remnant age, with best-fit lines drawn through maximum rates. To calculate errors in incision rates, vertical accuracy $( \pm 30 \mathrm{~m})$ of the Shuttle Radar Topography Mission digital elevation model is weighted against remnant ages. Graph shows a three-phase incision history for the Ethiopian Plateau, also seen in river long-profiles (Fig. 6). Phase III line is interpolated backward to predict its initiation. Major geologic event chronology to compare incision history: $30 \mathrm{Ma}$-flood volcanism, Simen volcano; $24 \mathrm{Ma}$-Afar depression formed; 22 Ma-Choke and Guguftu volcanoes developed; 20 Ma-Danakil Block separated; 10.7-8.4 Ma-second major episode of volcanism, including Guna shield volcano; $10 \mathrm{Ma}$-Gulf of Aden seafloor spreading; 6-5 Ma-Main Ethiopian Rift initiated; 5.9 Ma-Messinian salinity crisis; $5 \mathrm{Ma}$-Red Sea seafloor spreading; $4 \mathrm{Ma}$-third major episode of volcanism; 3 Ma-eastern African climate and vegetation change and hominin evolution.

or incision rate (e.g., due to variable erodibility of bedrock lithology) will result in a new equilibrium slope at a knickpoint, which separates the older, upstream, channel profile from the younger, downstream, channel profile. These knickpoints migrate headward as upstream-propagating waves of erosion (Weissel and Seidl, 1998; Whipple and Tucker, 1999), and migration is faster in the trunk stream than in the tributaries (Whipple and Tucker, 1999; Crosby and Whipple, 2006). Therefore, tributaries tend to preserve the record of base-level changes as a series of knickpoints still propagating upstream, and the number of subprofiles in a stream should correspond to the number of incision phases of the drainage basin. Because, with time, younger knick faces can overtake and remove older knick faces and selectively erode out older profiles, all incision phases may not be preserved in a stream profile.

Using DEM, longitudinal profiles of the Blue Nile River and seven major tributaries were extracted (Fig. 6). Field investigation and structural mapping of the region (Gani and Abdelsalam, 2006; Gani, 2006) ensure that no major faults cross these streams. Among the seven tributaries, two show one channel profile, four show two subprofiles (Figs. 6C and DR3 [GSA Data Repository; see footnote 1]), and one tributary, Birr, preserves three subprofiles (Fig. 6B), suggesting three phases of incision in the study area. This is consistent with the three incision phases described earlier, based on variations of long-term incision rates (Fig. 5). For the Guder, Muger, and Jema tributaries, each with two subprofiles (Figs. 6C and DR3), the migration of the youngest phase III knick face is interpreted to have eroded out the intermediate phase II subprofile. No major knickpoint was observed in the long-profile of the Blue Nile, which suggests 

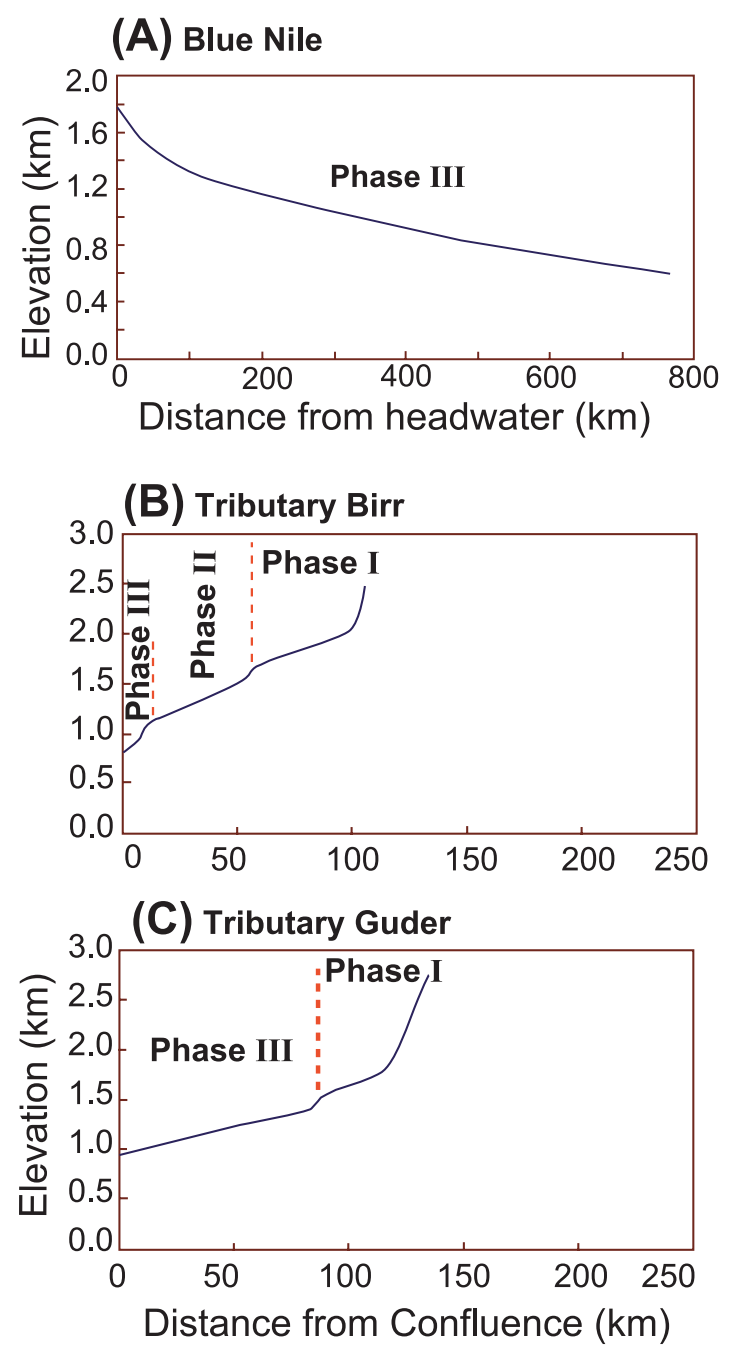

Figure 6. River longitudinal profiles, extracted from a digital elevation model, of the Blue Nile $(A)$ and two representative tributaries (B and C). Phases of incision interpreted from preserved major (relief $>200$ m) knick faces, which can overtake and remove older knick faces by upstream-migration. Tributary Birr (B) preserves all three phases of incision, consistent with the numbers of incision phases interpreted in Figure 5. See Figures 2 and 3 for tributary and knickpoint locations.

that all knickpoints passed through this trench and that the profile probably represents phase III incision (Fig. 6A).

Knickpoint origins and dynamics are debated (for a discussion, see Crosby and Whipple, 2006), and caution is required when causes of knickpoint formation are interpreted. Our tributary knickpoints (with knick-face relief $>200 \mathrm{~m}$ ) are unassociated with stream capture, faulting, or differential bedrock erosion (GSA Data Repository [footnote 1]). Therefore, we argue that these major knickpoints are likely related to uplift events that affected the plateau.

\section{Rock Uplift of the Ethiopian Plateau}

As indicated by the present elevation of the contact between the Jurassic Upper Limestone and Cretaceous Upper Sandstone, the net rock uplift of the Ethiopian Plateau is $2.2 \mathrm{~km}$ since ca. $150 \mathrm{Ma}$. The majority of this uplift occurred during the Cenozoic. The plateau was close to sea level in the middle
Eocene and experienced a domal uplift of $\sim 1 \mathrm{~km}$ by the early Oligocene, an uplift attributable to the rise of the Afar mantle plume ( engör, 2001). Hence, the stratigraphic contact (between Jurassic and Cretaceous rocks) was at $\sim 1 \mathrm{~km}$ elevation by the early Oligocene. The $\sim 1-\mathrm{km}$-thick, ca. $30 \mathrm{Ma}$ basalt would have caused subsidence of the plateau, although the abnormal thermal structure below the plateau might have complicated the situation. Using Archimedes' principle, isostatic adjustment (uplift or subsidence) of the crust due to exhumation $( \pm$ ) is given as (Isostatic adjustment) $=$ Exhumation $\times$ (Crust density/ Mantle density) (Molnar and England, 1990; Molnar, 2003; Pederson et al., 2002). If we use a mantle density of $3300 \mathrm{~kg} / \mathrm{m}^{3}$, then a basalt pile with mean thickness of $1 \mathrm{~km}$ and density of $2800 \mathrm{~kg} / \mathrm{m}^{3}$ results in $0.85 \mathrm{~km}$ of plateau subsidence. Ignoring flexural effect, this subsidence would have lowered the stratigraphic contact to an elevation of $\sim 0.15 \mathrm{~km}$ (despite the subsidence, the mean surface elevation of the basalt-covered plateau would have been $\sim 1.15 \mathrm{~km}$ ). Hence, the net rock uplift of the Ethiopian Plateau since ca. $30 \mathrm{Ma}$ has been $2.05 \mathrm{~km}$ $(2.2-0.15=2.05 \mathrm{~km})$. Since ca. $29 \mathrm{Ma}, 93,200 \mathrm{~km}^{3}$ rocks were removed from the plateau by river incision. As the study area is $250,000 \mathrm{~km}^{2}$, the mean thickness of the eroded material is $0.37 \mathrm{~km}$, the removal of which would be expected to result in $0.3 \mathrm{~km}$ isostatic uplift of the plateau, assuming a mean density of $2750 \mathrm{~kg} / \mathrm{m}^{3}$ for the removed rocks (granite, gneiss, sandstone, limestone, and basalt). Therefore, $1.75 \mathrm{~km}(2.05$ $-0.3=1.75 \mathrm{~km}$ ) of plateau rock uplift since ca. 30 Ma requires further explanation, probably involving the effects of plumerelated thermal uplift and flexural rift-flank uplift. However, the length-scale (a few tens of kilometers) of flexural uplift is likely too short to have a major role in uplifting the hundreds of kilometers-wide plateau.

\section{DISCUSSION AND CONCLUSIONS}

\section{River Incision and Plateau Growth}

Apart from direct base-level fall, two fundamental ways to substantially increase erosion in streams are to increase channel gradient via surface uplift driven by regional tectonics or to increase the ratio of discharge to sediment flux via climate change (cf. Tucker and Slingerland, 1997). In active terrains, the dominance of tectonic versus climate-driven river erosion is debated (Molnar and England, 1990; Whipple et al., 1999; Molnar, 2003), particularly in the light of late Cenozoic global climate change (Molnar and England, 1990; Hay et al., 2002; McMillan et al., 2006). Two of the most recent drastic climate changes in the Cenozoic occurred ca. $15 \mathrm{Ma}$ and ca. 3 Ma (Molnar and England, 1990; Hay et al., 2002). In Eastern Africa, a climate shift toward aridity and the change in vegetation from closed canopy to savannah occurred ca. $3 \mathrm{Ma}$ (deMenocal, 1995; Cane and Molnar, 2001). The long-term incision rate of the Blue Nile increased rapidly ca. $10 \mathrm{Ma}$ and ca. $6 \mathrm{Ma}$, increases that were out of phase with the climatic events and in phase with the major volcanic episodes of the region. Hence, we argue that such a deep and extensive incision of the Ethiopian Plateau is mostly related to its tectonic uplift history. If correct, then the magnitude and temporal variation of longterm incision rates of the Blue Nile can be used to constrain the plateau uplift. 
Our calculated long-term incision rate of $0.053 \mathrm{~mm} / \mathrm{yr}$ for the Blue Nile drainage since ca. $29 \mathrm{Ma}$ is of the same order as the value of $0.035 \mathrm{~mm} / \mathrm{yr}$ estimated by Pik et al. (2003). However, our results differ from their prediction that two-thirds of the total incision was achieved within the first 10 m.y. after the initiation and that the present physiography of the elevated plateau existed since the Oligocene, with erosion rate decreasing with time. In fact, identification of major knickpoints in tributary profiles (Fig. 6) suggests that pulses of erosional waves are still propagating in some parts of the drainage basin, indicating a non-equilibrium (i.e., transient) Ethiopian Plateau landscape. The Blue Nile incision history is expressed in the uplift-related knickpoints of stream profiles (Fig. 6) and in the changes of long-term incision rates (Fig. 5). The plateau experienced a slow and steady uplift rate, if any, between ca. 29 and ca. 10 $\mathrm{Ma}$, as indicated by the slow and near-steady incision of phase I. A rapid increase in long-term incision rate ca. $10 \mathrm{Ma}$ (beginning of phase II incision) was probably due to an increase in the uplift rate of the plateau at that time. The dramatic increase in long-term incision rate of the Blue Nile drainage started ca. 6 $\mathrm{Ma}$ (Fig. 5; initiation of phase III incision), indicating a dramatic plateau rise.

A close temporal correlation exists between the incision phases of the Blue Nile we interpret and the major volcanic episodes in the region as described by Abebe et al. (2005). After the extensive volcanism of the ca. $30 \mathrm{Ma}$ flood basalt, the region experienced a relatively quiescent phase of volcanism lasting until $10.6 \mathrm{Ma}$ that matches our phase I incision characterized by low and stable long-term incision rates. The next major volcanic episodes occurred between 10.6 and 8.4 Ma and ca. 4 Ma (Abebe et al., 2005), corresponding to our phase II and phase III incisions, respectively. This correlation independently supports our suggestion of a tectonically driven Ethiopian Plateau incision, because thermal heating tends to drive uplift.

Although a mean uplift rate of $0.1 \mathrm{~mm} / \mathrm{yr}$ since the Eocene has been suggested for the Ethiopian Plateau (Faure, 1973), the temporal distribution of $\sim 2 \mathrm{~km}$ rock uplift of the plateau since ca. $30 \mathrm{Ma}$ is poorly constrained. Considering the long-term incision rate (Fig. 5) as a proxy for plateau uplift, our study indicates that the Ethiopian Plateau did not appear to experience a steady growth since ca. 30 Ma. Rather, as reflected in the three-phase incision history of the region, the growth of the plateau was likely episodic in nature, resulting in a pulsed plateau growth similar (in terms of tempo, but not mechanism) to what has been suggested for the Tibetan Plateau (Schoenbohm et al., 2004). Of most importance, we argue that the majority of the $\sim 2-\mathrm{km}$ rock uplift of the Ethiopian Plateau occurred within a few m.y. after ca. $6 \mathrm{Ma}$. This is in line with the prediction of a rapid uplift of the plateau in the Plio-Pleistocene by Mohr (1967) and Adamson and Williams (1987). A paleo-floral study of a lacustrine deposit located north of Lake Tana (Yemane et al., 1985) also indicates plateau uplift of $\sim 1 \mathrm{~km}$ sometime between $8 \mathrm{Ma}$ and the present.

\section{Pliocene Uplift of the Plateau}

Potential causes of large and rapid uplift of the Ethiopian Plateau include delamination or convective removal of lithospheric mantle (e.g., Duggen et al., 2003; Molnar et al., 1993). Broad, dynamic uplift of the large Afar dome during the Eocene and early Oligocene was probably caused by buoyant pressure from a deep mantle plume (Davis and Slack, 2002) on an intact lithosphere. Preexisting topography (e.g., thinned lithosphere beneath the Mesozoic rifts, which exists within the Ethiopian Plateau; Mege and Korme, 2004; Gani, 2006) at the base of the lithosphere might have caused localized ponding of plume material (Ebinger and Sleep, 1998), which tends to cause thermal erosion of the overriding lithosphere and consequent uplift of the overlying crust (e.g., Johnston and Thorkelson, 2000). Prolonged heating of the $\sim 120-\mathrm{km}$-thick (cf. Ebinger and Sleep, 1998) lithosphere beneath the Ethiopian Plateau might have weakened it, so that at one stage, likely ca. $6 \mathrm{Ma}$, part of the lithosphere might have foundered rapidly into the plume, causing a large and rapid uplift of the plateau. A major phase of normal faulting ca. $5.2 \mathrm{Ma}$ that created the Main Ethiopian Rift and a major episode of volcanism in the region ca. $4 \mathrm{Ma}$ (Abebe et al., 2005; Bonini et al., 2005) may also attest to this massive uplift of the Ethiopian Plateau.

There exists an intriguing temporal correlation between the rapid uplift of the Ethiopian Plateau after ca. $6 \mathrm{Ma}$ and the Messinian salinity crisis (MSC) of the Mediterranean between 5.96 and $5.33 \mathrm{Ma}$ (Hsü et al., 1977; Krijgsman et al., 1999). Semiglobal reorganization of plates and renewed tectonic activities immediately before and after the MSC have been documented (Adamson and Williams, 1987; Adamson et al., 1992; Krijgsman et al., 1999; Duggen et al., 2003). Unloading and loading of $\sim 2 \mathrm{~km}$ of seawater in the Mediterranean along with deposition of a $\sim 1-\mathrm{km}$-thick halite layer within $<0.5 \mathrm{~m}$.y. would have created great mechanical stresses and isostatic adjustments of the lithosphere in and around the region (Norman and Chase, 1986; Adamson et al., 1992). It is possible that these stresses propagated through the lithosphere via stress diffusion and aided in the foundering of already weakened lithosphere beneath the Ethiopian Plateau, causing the plateau to rise $>1$ $\mathrm{km}$ within a few m.y. In fact, substantial uplift of the East African Rift System has been documented between 5 and $2 \mathrm{Ma}$ (see references in Sepulchre et al., 2006; Spiegel et al., 2007). Seafloor spreading in the Red Sea also initiated ca. $5 \mathrm{Ma}$ (Ukstins et al., 2002).

\section{Paleoclimate and Hominin Evolution}

A global-scale change from $\mathrm{C}_{3}$-photosynthesizing (wooddominated) vegetation to $\mathrm{C}_{4}$ (grass-dominated) vegetation in the late Miocene ( $8-6 \mathrm{Ma}$ ) has been suggested by stable carbon isotope analysis of fossil tooth enamel (Cerling et al., 1997). Compilation of paleoclimatic data by Cane and Molnar (2001) suggests that this woodland to grassland transition, indicative of increasing aridification, took place ca. 3-4 Ma in East Africa. In the late Pliocene and Pleistocene, several brief ( $\sim 0.2$ m.y.) wet periods were superimposed on this longer-term aridification (lake sediments study of Trauth et al., 2005). These climatic changes have been attributed to decreased sea-surface temperatures related to the onset of Northern Hemisphere glacial cycles (deMenocal, 1995) and/or to the closing of the Indonesian seaway (Cane and Molnar, 2001). However, in explaining East African aridification, Pickford (1990) argued for the late Neogene uplift of the Roof of Africa, the 6000-km-long, northsouth-oriented East African Rift System rising to $5.1 \mathrm{~km}$. In an atmospheric and biospheric simulation, Sepulchre et al. (2006) 
concluded that the uplift of eastern African topography had a first-order impact on this aridification by inhibiting a zonal circulation of moist air. Asynchronous uplift of the Roof of Africa during the late Neogene and isolated topographic features like volcanoes might have permitted temporally and spatially restricted humid conditions within the overall arid landscape. Hence, the $>1 \mathrm{~km}$ uplift of the Ethiopian Plateau shortly after ca. 6 Ma likely played a key role in the East African aridification by forming orographic barriers to moist air.

East African aridification caused a gradual replacement of closed forest woodlands by open savanna grasslands. Darwin (1871, as cited in Potts, 1998) pioneered the "Savanna Hypothesis" by suggesting, in summary, that human evolution was a consequence of adaptive change on the African savanna. Hence, it is possible that the massive uplift of the Ethiopian Plateau in the Pliocene was critical in the origin, adaptation, and/or demise of East African hominins, particularly forcing an arid-adaptive evolutionary path for Homo sapiens (e.g., Reed, 1997; deMenocal, 1995).

\section{ACKNOWLEDGMENTS}

The Ethiopian Geological Survey provided critical support during field work. Solomon Gera, Linda Smith, and local Ethiopian people assisted in the field. Chris Kesler helped with GIS, and Phil Wannamaker edited a version of the manuscript. Critical comments provided by Martin Casey, Eduardo Garzanti, John Holbrook, Raphael Pik, Martin Williams, GSA Today editor Stephen Johnston, and an anonymous reviewer significantly improved the quality of this manuscript. Part of this study was originally carried out at the Geosciences Department, University of Texas at Dallas. The U.S. National Aeronautics and Space Administration provided shuttle radar topography mission elevation data. Partial funding for this research was provided by National Science Foundation grant INT-0323737.

\section{REFERENCES CITED}

Abebe, T., Maetti, P., Bonini, M., Corti, G., Innocenti, F., Mazzarini, F., and Pecksay, Z., 2005, Geological map of the northern Main Ethiopian Rift and its implications for the volcano-tectonic evolution of the rift: Geological Society of America Map and Chart Series MCH094, scale 1:200,000, 20 p.

Adamson, D., and Williams, M.A.J., 1987, Geological setting of Pliocene rifting and deposition in the Afar Depression of Ethiopia: Journal of Human Evolution, v. 16, p. 597-610, doi: 10.1016/0047-2484(87)90015-7.

Adamson, D., McEvedy, R., and Williams, M.A.J., 1992, Tectonic inheritance in the Nile basin and adjacent areas: Israel Journal of Earth Sciences, v. 41, p. $75-85$.

Ayalew, L., and Yamagishi, H., 2004, Slope failure in the Blue Nile basin, as seen from landscape evolution perspective: Geomorphology, v. 1361, p. 1-22.

Beyene, A., and Abdelsalam, M.G., 2005, Tectonics of the Afar Depression: A review and synthesis: Journal of African Earth Sciences, v. 41, p. 41-59, doi: 10.1016/ j.jafrearsci.2005.03.003.

Bonini, M., Corti, G., Innocenti, F., and Manetti, P., 2005, Evolution of the Main Ethiopian Rift in the frame of Afar and Kenya rifts propagation: Tectonics, v. 24, doi: 10.1029/2004TC001680.

Cane, M.A., and Molnar, P., 2001, Closing of the Indonesian seaway as a precursor to east African aridification around 3-4 million years ago: Nature, v. 411, p. 157-162, doi: 10.1038/35075500.

Capaldi, G., Chiesa, S., Manetti, P., Orsi, G., and Poli, G., 1987, Tertiary anorogenic granites of the western border of the Yemen Plateau: Lithos, v. 20, p. 433-444, doi: 10.1016/0024-4937(87)90028-4

Cerling, T.E., Harris, J.M., MacFadden, B.J., Leakey, M.G., Quade, J., Eisenmann, V., and Ehleringer, J.R., 1997, Global vegetation change through the Miocene/ Pliocene boundary: Nature, v. 389, p. 153-158, doi: 10.1038/38229.

Chorowicz, J., Collet, B., Bonavia, F.F., Mohr, P., Parrot, J.F., and Korme, T., 1998, The Tana basin, Ethiopia: Intra-plateau uplift, rifting and subsidence: Tectonophysics, v. 295, p. 351-367, doi: 10.1016/S0040-1951(98)00128-0.

Clark, M.K., Schoenbohm, L.M., Royden, L.H., Whipple, K.X., Burchfiel, B.C., Zhang, X., Than, W., Wang, E., and Chen, L., 2004, Surface uplift, tectonics, and erosion of eastern Tibet from large-scale drainage patterns: Tectonics, v. 23 TC1006, doi: 10.1029/2002TC001402.
Clark, M.K., Maheo, G., Saleeby, J., and Farley, K.A., 2005, The non-equilibrium landscape of the southern Sierra Nevada, California: GSA Today, v. 15, p. 4-10, doi: 10.1130/1052-5173(2005)015[4:TNLOTS]2.0.CO;2.

Collet, B., Taud, H., and Parrot, J.F., 1999, Altimetric anomalies in the Afro-Arab zone: Eclogae Geologicae Helvateae, v. 92, p. 275-284.

Coulie, E., Quidelleur, X., Gillot, P.Y., Coutillot, V., Lefevre, J.C., and Chiessa, S., 2003, Comparative K-Ar and Ar/Ar dating of Ethiopian and Yemenite Oligocene volcanism: Implication for timing and duration of the Ethiopian traps: Earth and Planetary Science Letters, v. 206, p. 477-492, doi: 10.1016/S0012$821 \times(02) 01089-0$.

Crosby, B.T., and Whipple, K.X., 2006, Knickpoint initiation and distribution within fluvial networks: 236 waterfalls in the Waipaoa River, North Island, New Zealand: Geomorphology, v. 82, p. 16-38, doi: 10.1016/j.geomorph.2005.08.023.

Darwin, C., 1871, The Descent of Man and Selection in Relation to Sex: Murray, London, $409 \mathrm{p}$.

Davis, P.M., and Slack, P.D., 2002, The uppermost mantle beneath the Kenya dome and relation to melting, rifting and uplift in East Africa: Geophysical Research Letters, v. 29, doi: 10.1029/2001GL013676.

deMenocal, P.B., 1995, Plio-Pleistocene African climate: Science, v. 270, p. 53-59, doi: 10.1126/science.270.5233.53.

Duggen, S., Hoernle, K., van den Bogaard, P., Rüpke, L., and Morgan, J.P., 2003, Deep roots of the Messinian salinity crisis: Nature, v. 422, p. 602-606, doi: 10.1038/nature01553.

Ebinger, C.J., and Sleep, N.H., 1998, Cenozoic magmatism throughout east Africa resulting from impact of a single plume: Nature, v. 395, p. 788-791, doi: $10.1038 / 27417$.

Faure, H., 1973, Neotectonics in the Afar (Ethiopia. T.F.A.I.): Congress of the International Union for Quaternary Research, v. 9, p. 93-94.

Gani, N.D., 2006, Geological evolution and incision history of the Gorge of the Nile on Ethiopian Plateau from remote sensing and geographic information system analysis, and field studies [Ph.D. dissertation]: University of Texas at Dallas, $128 \mathrm{p}$.

Gani, N.D., and Abdelsalam, M.G., 2006, Remote sensing analysis of the Gorge of the Nile, Ethiopia with emphasis on Dejen-Gohatsion region: Journal of African Earth Sciences, v. 44, p. 135-150, doi: 10.1016/j.jafrearsci.2005.10.007.

Gardner, T.W., Jorgensen, D.W., Shuman, C., and Lemieux, C.R., 1987, Geomorphic and tectonic process rates: Effects of measured time interval: Geology, v. 15, p. 259-261, doi: 10.1130/0091-7613(1987)15<259:GATPRE>2.0.CO;2.

Garzanti, E., Ando, S., Vezzoli, G., Megid, A.A.A., and El Kammar, A., 2006, Petrology of Nile River sands (Ethiopia and Sudan): Sediment budget and erosion patterns: Earth and Planetary Science Letters, v. 252, p. 327-341, doi: 10.1016/ j.epsl.2006.10.001.

Hay, W.W., Soeding, E., DeConto, R.M., and Wold, C.N., 2002, The Late Cenozoic uplift-climate change paradox: International Journal of Earth Sciences, v. 91, p. 746-774, doi: 10.1007/s00531-002-0263-1.

Hofmann, C., Courtillot, V., Feraud, G., Rochette, P., Yirgu, G., Ketefo, E., and Pik, R., 1997, Timing of the Ethiopian flood basalt event and implications of Plume birth and global change: Nature, v. 389, p. 838-841, doi: 10.1038/39853.

Hsü, K.J., Montadert, L., Bernoulli, D., Cita, M.B., Erickson, A., Garrison, R., Kidd, R.B., Melieres, F., Müller, C., and Wright, R., 1977, History of the Mediterranean salinity crisis: Nature, v. 267, p. 399-403, doi: 10.1038/267399a0.

Johnston, S.T., and Thorkelson, D.J., 2000, Continental flood basalts: Episodic magmatism above long-lived hotspots: Earth and Planetary Science Letters, v. 175, p. 247-256, doi: 10.1016/S0012-821X(99)00293-9.

Kenney, B.C., 1982, Beware of spurious self-correlations!: Water Resources Research, v. 18, p. 1041-1048.

Kieffer, B., Arndt, N., Lapierre, H., Bastien, F., Bosch, D., Pecher, A., Yirgu, G., Ayalew, D., Weis, D., Jerram, D.A., Keller, F., and Meugniot, C., 2004, Flood and shield basalts from Ethiopia: Magmas from the African Superswell: Journal of Petrology, v. 45, p. 793-834, doi: 10.1093/petrology/egg112.

Krijgsman, W., Hiigeni, F.J., Raffi, I., Sierro, F.J., and Wilson, D.S., 1999, Chronology, causes and progression of the Messinian salinity crisis: Nature, v. 400, p. 652655, doi: 10.1038/23231

Mangesha, T., Chernet, T., and Haro, W., 1996, Geological map of Ethiopia: Addis Ababa, Ethiopia, Geological Survey of Ethiopia, scale 1:2,000,000.

Manighetti, I., Tapponnier, P., Courtillot, V., Gallet, Y., Jacques, E., and Gillot, P.Y., 2001, Strain transfer between disconnected, propagating rifts in Afar: Journal of Geophysical Research, v. 106, p. 13,613-13,665, doi: 10.1029/2000JB900454.

McDougall, I., Morton, W.H., and William, M.A.J., 1975, Ages and rates of denudation of trap series basalts at the Blue Nile Gorge, Ethiopia: Nature, v. 254, p. 207-209, doi: 10.1038/254207a0.

McMillan, M.E., 2003, Basinfill erosion surfaces and tilted markers: Evidence of Late Cenozoic tectonic uplift of the Rocky Mountain Orogenic Plateau [Ph.D. dissertation]: Laramie, University of Wyoming, $127 \mathrm{p}$.

McMillan, M., Heller, P., and Wing, S., 2006, History and causes of post-Laramide relief in the Rocky Mountain orogenic plateau: Geological Society of America Bulletin, v. 118, p. 393-405, doi: 10.1130/B25712.1.

Mege, D., and Korme, T., 2004, Dyke swarm emplacement in the Ethiopian large igneous province: Not only a matter of stress: Journal of Volcanology and Geothermal Research, v. 132, p. 283-310, doi: 10.1016/S0377-0273(03)00318-4.

Mohr, P., 1967, Review of the Geology of Simen Mountains: Addis Ababa University, Addis Ababa, Ethiopia, Bulletin of Geophysical Observatory, v. 10, p. 79-93. 
Mohr, P., and Zanettin, B., 1988, The Ethiopian Flood Basalt Province, in McDougall, J.D., ed., Continental Flood Basalts: Dordrecht, Netherlands, Kluwer Academic Publishers, p. 63-110.

Molnar, P., 2003, Nature, nurture and landscape: Nature, v. 426, p. 612-614, doi $10.1038 / 426612 a$

Molnar, P., and England, P., 1990, Late Cenozoic uplift of mountain ranges and global climate change: Chicken or egg?: Nature, v. 346, p. 29-34, doi: 10.1038/346029a0.

Molnar, P., England, P., and Martinod, J., 1993, Mantle dynamics, uplift of the Tibetan Plateau, and the Indian Monsoon: Reviews of Geophysics, v. 31, p. 357-396, doi: 10.1029/93RG02030.

Norman, S.E., and Chase, C.G., 1986, Uplift of the shores of the western Mediterranean due to Messinian desiccation and flexural isostasy: Nature, v. 322, p. 450-452, doi: 10.1038/322450a0

Pederson, J.L., Mackley, R.D., and Eddleman, J.L., 2002, Colorado Plateau uplift and erosion evaluated using GIS: GSA Today, v. 12, p. 4-10, doi: 10.1130/10525173(2002)012<0004:CPUAEE >2.0.CO;2

Pickford, M., 1990, Uplift of the roof of Africa and its bearing on the evolution of mankind: Journal of Human Evolution, v. 5, p. 1-20, doi: 10.1007/BF02436472.

Pik, R., Marty, B., Carignan, J., and Lave, J., 2003, Stability of Upper Nile drainage network (Ethiopia) deduces from (U-Th)/He thermochronometry: Implication of uplift and erosion of the Afar plume dome: Earth and Planetary Science Letters, v. 215, p. 73-88, doi: 10.1016/S0012-821X(03)00457-6.

Potts, R., 1998, Environmental hypotheses of hominin evolution: Yearbook of Physical Anthropology, v. 104, p. 93-136, doi: 10.1002/(SICI)10968644(1998)107:27+<93::AID-AJPA5>3.0.CO;2-X.

Reed, K.E., 1997, Early hominid evolution and ecological change through the African Plio-Pleistocene: Journal of Human Evolution, v. 32, p. 289-322, doi: 10.1006/ jhev.1996.0106.

Schoenbohm, L.M., Whipple, K.X., Burchfiel, B.C., and Chen, L., 2004, Geomorphic constraints on surface uplift, exhumation, and plateau growth in the Red River region, Yunnan Province, China: Geological Society of America Bulletin, v. 116, p. 895-909, doi: 10.1130/B25364.1.

Şengör, A.M.C., 2001, Elevation as indicator of mantle-plume activity, in Ernst, R.E., and Buchan, K.L., eds., Mantle Plumes: Their identification through time: Geological Society of America Special Paper 352, p. 183-225.

Sepulchre, P., Ramstein, G., Fluteau, F., Schuster, M., Tierchelin, J., and Brunet, M., 2006, Tectonic uplift and eastern African aridification: Science, v. 313, p. 1419-1423, doi: 10.1126/science.1129158.

Spiegel, C., Kohn, B.P., Belton, D.X., and Gleadow, A.J.W., 2007, Morphotectonic evolution of the central Kenya rift flanks: Implications for late Cenozoic environmental change in East Africa: Geology, v. 35, p. 427-430, doi: 10.1130/ G23108A.1.
Trauth, M.H., Maslin, M.A., Deino, A., and Strecker, M.R., 2005, Late Cenozoic moisture history of East Africa: Science, v. 309, p. 2051-2053, doi: 10.1126/ science. 1112964

Tucker, G.E., and Slingerland, R., 1997, Drainage basin responses to climate change: Water Resources Research, v. 33, no. 8, p. 2031-2047, doi: 10.1029/97WR00409.

Ukstins, I.A., Renne, P.R., Wolfenden, E., Baker, J., Ayalew, D., and Menzies, M. 2002, Matching conjugate volcanic rifted margins: ${ }^{40} \mathrm{Ar} /{ }^{39} \mathrm{Ar}$ chrono-stratigraphy of pre- and syn-rift bimodal flood volcanism in Ethiopia and Yemen: Earth and Planetary Science Letters, v. 198, p. 289-306, doi: 10.1016/S0012 $821 \times(02) 00525-3$

Weissel, J.K., and Seidl, M.A., 1998, Inland propagation of erosional escarpments and river profile evolution across the southeast Australian passive continental margin, in Tinkler, K., and Wohl, E.E., eds., Rivers over rock: Fluvial processes in bedrock channels: American Geophysical Union Geophysical Monograph 107, p. 189-206.

Weissel, J K Malinverno, A and Harding DJ 1995, Erosional development of the Ethiopian plateau of Northeast Africa from fractal analysis of topography, in Barton, C.C., and La Pointe, P.R. eds., Fractals in Petroleum Geology and Earth Processes: New York, Plenum Press, p. 127-142.

Whipple K.X and Tucker, G.E 1999 Dynamics of the stream-power river incision model: Implications for height limits of mountain ranges, landscape response timescales, and research needs: Journal of Geophysical Research, v. 104, p. 17,661-17,674, doi: 10.1029/1999JB900120.

Whipple, K.X. Kirby, E., and Brocklehurst, S.H., 1999, Geomorphic limits to climate-induced increases in topographic relief: Nature, v. 401, p. 39-43, doi: $10.1038 / 43375$

WoldeGabriel, G., Aronson, J.L., and Walter, R.C., 1990, Geology, geochronology, and rift basin development in the central sector of the Main Ethiopia Rift: Geological Society of America Bulletin, v. 102, p. 439-458, doi: 10.1130/00167606(1990)102<0439:GGARBD>2.3.CO;2.

Wolfenden, E., Yirgu, G., Ebinger, C., Deino, A., and Ayalew, D., 2004, Evolution of the northern Main Ethiopian rift: Birth of a triple junction: Earth and Planetary Science Letters, v. 224, p. 213-228, doi: 10.1016/j.epsl.2004.04.022.

Yemane, K., Bonnefille, R., and Faure, H., 1985, Palaeoclimatic and tectonic implications of Neogene microflora from the northwest Ethiopian highlands: Nature, v. 318 , p. $653-656$, doi: $10.1038 / 318653 \mathrm{a} 0$.

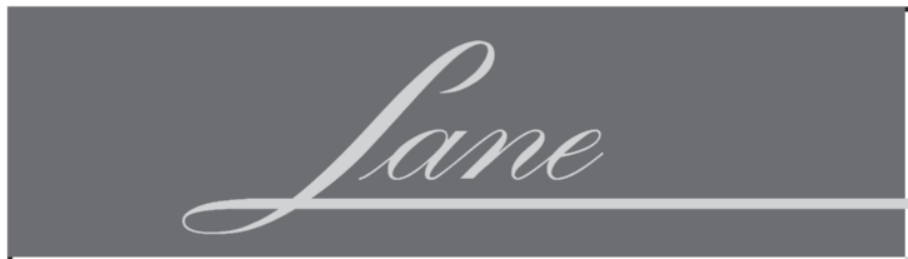

\section{GEOLOGY \& PALEONTOLOGY SPECIMEN CABINETS}

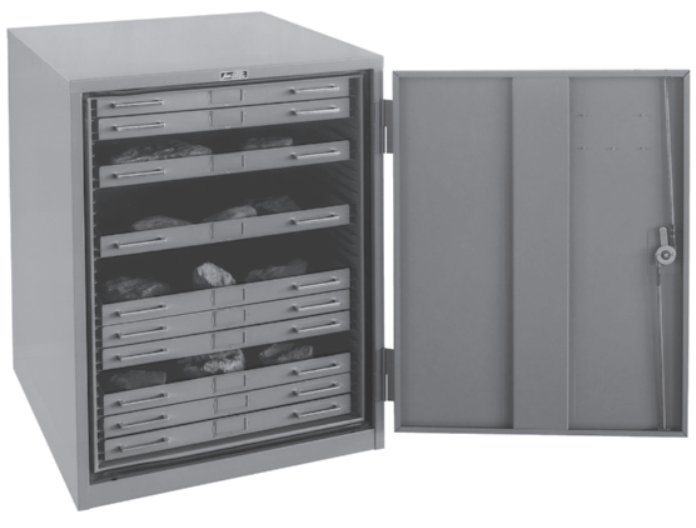

For over forty years, Lane Science Equipment has been the name museums, universities and individual collectors trust most to protect their valuable specimens.

To learn more about our Geology \& Paleontology Cabinets or any of our other products, visit our website at www.lanescience.com or contact us at the listing below.
* All steel construction
Powder paint finish
* No adhesives
Durable neoprene door seal
Lane lift-off door
Reinforced for easy stacking

LANE SCIENCE EQUIPMENT CORP.

225 West 34th Street

Suite 1412

New York, NY 10122-1496
Tel: 212-563-0663

Fax: 212-465-9440

www.Ianescience.com 